\title{
COUNCELING PATIENTS WITH ENDOMETRIOSIS
}

\author{
Sonja Pop Trajković Dinić1,2, Milan Stefanović1,2, Radomir Živadinović1,2, Vladimir Antić2, \\ Milan Trenkić1,2, Jelena Milošević Stevanović1,2
}

\begin{abstract}
Women with endometriosis often need some of the assisted reproductive techniques to conceive. Regarding literature, there is no consensus about the pregnancy outcome in patients with endometriosis who underwent in vitro fertilization. This study was undertaken to give the best direction for infertile patients with this problem regarding in vitro fertilization outcome. This study included 78 patients who underwent surgery for endometriosis. Forty patients were diagnosed with minimal and mild endometriosis (American Society for Reproductive Medicine stage I/II) and 38 patients with moderate and severe endometriosis (stage III/IV). IVF outcome was compared between 3 groups of patients. The first group included patients who had one surgery without endometriosis during IVF procedure, the second group included patients also with one surgery but with recurrent endometriosis during IVF and the third group included patients who had more than one surgery. Number of aspirated oocytes, pregnancy rates and live birth rates after IVF were compared between groups. IVF outcome in patients who had more than one surgery was significantly worse. Patents who had one surgery for endometriosis should be advised to go directly to IVF even if they have recurrent disease.
\end{abstract}

Acta Medica Medianae 2021;60(3):37-41.

Key words: endometriosis, in vitro fertilization, outcome

\footnotetext{
${ }^{1}$ University of Niš, Faculty of Medicine, Niš, Serbia

Obstetrics Clinic, Niš, Serbia

Contact: Sonja Pop Trajković Dinić

24/21 Oblačića Rada St., 18000 Niš, Serbia

E-mail: sonjapoptrajkovic@gmail.com
}

${ }^{2}$ University Clinical Center Niš Clinic for Gynecology and

\section{Introduction}

Endometriosis is a benign gynecologic disease which affects less than $10 \%$ of female population. In infertile females, the rate of endometriosis is between 20 and $50 \%$ and endometriosis is the fourth reason for including couples in IVF procedure (1). Endometriosis affects many aspect of natural conception such as folliculogenesis, maturation of oocyte, cleavage of embryo and implantation. It is well known that by using IVF some of those altered functions can be overcome (2).

Endometriosis is a recurrent disease. Depending on diagnostic criteria, the overall recurrence rate is between 6 and $67 \%$ (3).

Various studies have discussed IVF/ET outcome in patients with endometriosis. While some studies have reported poor IVF outcome in patients with this disease $(4,5)$, others claimed that IVF outcome in patients with endometriosis is comparable to those in couples with other causes of infertility $(6,7)$. Also, it still remains unclear what impact previous surgery and different stages of endometriosis have on IVF outcome.

\section{The aim}

The aim of this study was first to investigate whether or not stages of endometriosis had impact on IVF outcome. Second, considering the fact that many patients are entering IVF procedure with recurrent disease after surgery, the aim was to compare IVF outcomes in patients who underwent one with outcomes of those who had more than one surgery for endometriosis. We hope that this investigation will give some directions in counseling patients with endometriosis.

\section{Patients and methods}

During the period of three years, 235 patients who had first IVF cycle were analyzed. Seventyeight patients had endometriosis. All patients with endometriosis had one or more surgeries. In forty patients, histopathological verification after laparoscopy revealed minimal and mild endometriosis and in thirty-eight moderate and severe endometriosis. Sixty-eight patients underwent only one and 12 
more than one surgical procedure. The "stripping" technique was standard surgical procedure to excide endometriomas (the endometrioma was drained with aspiration and the psudocapsule was dissected by gentle traction and countertraction using two 5 $\mathrm{mm}$ grasping forceps) and the diagnosis was histologically confirmed. All patients with endometriosis were treated with 3-6 cycles of $\mathrm{GnRH}$ analogues after laparoscopy and prior to IVF. Depending on the women's age, the antral follicle count and the basal (day 3) FSH, the long GnRH-agonist down regulation protocol (Diphereline $0.1 \mathrm{mg}$, Ipsen Pharma Biotech, France), the short $\mathrm{GnRH}$-agonist or $\mathrm{GnRH}$ antagonist protocol (Cetrotide, Serono Pharma, Switzerland) were used. Ovulation stimulations were conducted with daily subcutaneous injections of individual starting doses of rFSH (Follitropin alpha-Gonal F, Serono Pharma Switzerland or Follitropin beta-Puregon, Organon, Netherlands) or hMG (Menopur, Ferring Germany) at appropriate doses (50-450 IU). Ovarian response to gonadotropins was monitored by transvaginal ultrasound and serum E2 measurement every second day from day 7. Ovulation was triggered by injecting 10,000 IU hCG when the leading follicle reached $18 \mathrm{~mm}$ with appropriate serum E2 levels. Thirty-six hours after administration of hCG transvaginal, ultrasound-guided oocyte aspiration was performed under local anesthesia. After cultivation, embryo transfer was performed 3 to 5 days after oocytes aspiration. All patients received luteal phase support for 2 weeks. Clinical pregnancy was defined as the visualization of gestational sac at ultrasound examination and biochemical pregnancy was defined as detection of beta HCG levels in serum but no signs of pregnancy were revealed by ultrasound.

Data are expressed as the mean \pm standard deviation or as percentages when required. Statistical comparisons among groups were performed using the Fisher exact test, $\chi^{2}$ test, Wilcoxon's test or Student's t test as appropriate. Significance was defined as a $p$ value $<0.05$.

\section{Results}

IVF laboratory parameters and IVF outcomes compared among patients with different stages of endometriosis are presented in Table 1. Patients with endometriosis stage III and IV had significantly higher cycle cancellation rate and higher fertilization rate but on the other hand lower number of retrieved oocytes, total number of embryos and lower implantation rate compared to patients with stage I and II of endometriosis. Clinical pregnancy rates and live birth rates were significantly lower in patients with endometriosis stage III and IV compared with milder stages of endometriosis.

Table 1. IVF outcome including laboratory data in women with different stages of endometriosis.

\begin{tabular}{||l|c|c|c||}
\cline { 2 - 4 } \multicolumn{1}{c||}{} & Stage I/II & Stage III/IV & P value \\
\hline Rate of cancelation (\%) & 12.7 & 20.8 & $<0.05$ \\
\hline No. of oocytes retrieved & 5.9 & $3.6 \pm 3.4$ & $<0.05$ \\
\hline Rate of fertilization (\%) & 49.5 & 59.8 & NS \\
\hline No. of obtained embryos & $3 \pm 1.9$ & $1.9 \pm 1.6$ & $<0.01$ \\
\hline Implantation rate(\%) & 25.7 & 17.6 & $<0.05$ \\
\hline Pregnancy rate per ET (\%) & 43.2 & 31.03 & $<0.05$ \\
\hline Live birth rate per ET (\%) & 28.8 & 20.7 & $<0.05$ \\
\hline \hline
\end{tabular}

Data are expressed as mean \pm SD when appropriate.

Table 2 shows IVF laboratory parameters as well as the IVF outcome in three groups of patients with endometriosis (operated once with no signs of endometriosis at the time of entering the IVF treatment, operated once with recurrent endometriosis at the time of inclusion in IVF and those operated two or more times). The rate of canceled cycles was significantly higher in patients who underwent two or more endometriosis surgeries. The same went for the number of oocytes retrieved by puncture and the number of the obtained embryos. The rate of implantation, clinical pregnancies, as well as the birth rate per embryo transfer was significantly lower in patients who underwent endometriosis surgery two or more times, compared with all other groups of patients. Among the patients who had one surgery with or without recurrent endometriosis at the time of entering the IVF treatment, there were no differences in any of the examined parameters apart from the miscarriage rate, which was higher in patients with recurrent endometriosis compared with all other examined groups of women. 
Table 2. IVF outcome including laboratory data

\begin{tabular}{||l|c|c|c|c|c||}
\cline { 2 - 6 } \multicolumn{1}{c|}{} & A & B & C & B vs A & C vs A, B \\
\hline Rate of cancellation (\%) & $13.7^{* *}$ & $14.2^{* *}$ & $27.2^{* * * *}$ & NS & $\mathrm{p}<0.05$ \\
\hline No. of oocytes & $5.9 \pm 3.1^{*}$ & $5.6 \pm 2.9^{*}$ & $3.9 \pm 2.25^{* * *}$ & $\mathrm{NS}$ & $\mathrm{p}<0.01$ \\
\hline Rate of fertilization (\%) & 53.7 & 53.6 & 47.2 & $\mathrm{NS}$ & $\mathrm{NS}$ \\
\hline No. of embryos & $3 \pm 2.5^{*}$ & $2.9 \pm 2.2^{*}$ & $1.8 \pm 1.2^{* * *}$ & $\mathrm{NS}$ & $\mathrm{p}<0.01$ \\
\hline Implantation (\%) & 22.37 & 24.8 & $13.8^{* *}$ & $\mathrm{NS}$ & $\mathrm{p}<0.01$ \\
\hline Pregnancies per ET (\%) & 47.9 & 46.4 & $25.1^{* *}$ & $\mathrm{NS}$ & $\mathrm{p}<0.01$ \\
\hline No. of miscarriages (\%) & 22.2 & $31.2^{*}$ & 24.2 & $\mathrm{p}<0,05$ & $\mathrm{p}<0.05(\mathrm{~B}$ vs C) \\
\hline Deliveries per ET (\%) & 28.1 & 27.1 & $18.1^{*}$ & $\mathrm{NS}$ & $\mathrm{p}<0.05$ \\
\hline
\end{tabular}

A - patients with one surgery for endometriosis;

$\mathrm{B}$ - patients with one surgery for endometriosis with recurrent disease;

$\mathrm{C}$ - patients with more than one surgery for endometriosis;

$* \mathrm{p}<0.05$; ** $\mathrm{p}<0.01$; *** $\mathrm{p}<0.005$; **** $\mathrm{p}<0.001$.

\section{Discussion}

According to our results, almost all aspects of IVF are negatively influenced by moderate and severe endometriosis, from ovarian response during gonadotropin stimulation to implantation and pregnancy rate. The only exception was fertilization rate.

The fertilization rate in women with severe endometriosis was higher than that in women with minimal and mild endometriosis. One possible explanation for this may be that lesions associated with severe endometriosis are burned out lesions resulting in pelvic adhesions rather than lesions with active endometrial glands. Thus, it may be the secretory components of an active lesion that are affecting oocyte quality and thus fertilization which is the case in milder endometriosis. This supports the results of previous studies showing an increase in chemotactic activity in the peritoneal fluid of women with active endometriosis lesions (8-10).

Patients with advanced stages of endometriosis had lower pregnancy and live birth rate compared with patients with minimal and mild endometriosis. Results from the literature are similar. One study showed $60 \%$ pregnancy rate per ET in women with stage I and II of endometriosis and only $7 \%$ in women with endometriosis stage III and IV (11). Four other studies also presented significantly lower pregnancy and live birth rate in patients with stage III and IV endometriosis (12-15). Regarding the fact that patients with advanced endometriosis have lower pregnancy and multifetal rate and that fertilization rate is not impaired, it can be concluded that in fact, it is endometrial receptivity which is negatively affected in these patients. More studies are needed to support this theory. Our data have several clinical implications. First of all, they suggest that IVF outcome is influenced by different stages of endometriosis through different mechanisms. Moderate and severe endometriosis have detrimental effect on ovarian response during stimulation, cycle cancellation rate and implantation rate. Minimal and mild endometriosis impair fertilization rate due to presentation of lesions with active endometrial glands.

Regarding the recurrence of endometriosis, a certain number of patients who undergo surgery for endometriosis will experience recurrent endometriosis, whereas infertile patients who wish to achieve pregnancy may also face a dilemma of whether or not to undergo repeat surgery.

There is little information in the literature about the benefit of repeated surgery for the reproductive outcome. One study has shown a significantly higher rate of spontaneous pregnancies after the first surgical treatment of endometriosis (40\%), compared to the rate after a repeat surgery $(22 \%)$ (16).

Other study has revealed a conception rate of $26 \%$ among women undergoing repetitive surgery for recurrent endometriosis associated with infertility, compared to a reported overall crude pregnancy rate of $41 \%$ after a primary procedure (17).

This study has compared the IVF outcomes among patients who have undergone one surgical treatment for endometriosis, patients with recurrent endometriosis after the primary surgery who entered the IVF treatment and those who have undergone two or more endometriosis surgeries. In our study, patients having undergone two or more surgical interventions for endometriosis had a significantly worse ovarian response to controlled hyperstimulation as well as worse IVF outcomes, compared with all other groups of patients. It seems that a repeat surgery after the ovarian response has been already quantitatively reduced by the previous surgery and a subsequent disease which per se affects healthy ovarian tissue, significantly impairs ovarian reserve which is defenitely reflected by a poor/bad IVF outcome. 


\section{Conclusion}

The ASRM classification of endometriosis is useful in predicting the IVF outcome. Stage III and IV endometriosis mean a worse prognosis for IVF treatment compared to milder stages. When it comes to recurrent endometriosis, a repeat surgery worsens the IVF outcome and therefore should be avoided.

\section{References}

1. Batt RE. Emergence of endometriosis in North America: a study in the history of ideas [dissertation]. Buffalo (NY): Faculty of the Graduate School of the University of Buffalo, State University of New York; 2008.

2. Milingos S, Protopapas A, Kallipolitis G. Laparoscopic evaluation of infertile patients with chronic pelvic pain. Reproductive BioMedicine Online 2002;12:347-53. [CrossRef] [PubMed]

3. Milingos S, Mavrommatis C, Elsheikh A. Fecundity of infertile women with minimal or mild endometriosis. A clinical study. Archives of Gynecology and Obstetrics 2002;267:37-40. [CrossRef] [PubMed]

4. Bulletti C, Coccia ME, Battistoni S, Borini A. Endometriosis and infertility. J Assist Reprod Genet 2010; 27(8):441-7. [CrossRef] [PubMed]

5. Geber S, Ferreira DP, Spyer Prates LF. Effects of previous ovarian surgery for endometriosis on the outcome of assisted reproduction treatment. Reproductive BioMedicine Online 2002;5:162-6. [CrossRef] [PubMed]

6. Suganuma N, Wakahara Y, Ishida D. Pretreatment for ovarian endometrial cyst before in vitro fertilization. Gynecologic and Obstetric Investigation 2002;54(1): 36-40, discussion 41-2. [CrossRef] [PubMed]

7. Tinkanen $\mathrm{H}$, Kujansuu $\mathrm{E}$. In vitro fertilization in patients with ovarian endometriomas. Acta Obstetricia et Gynecologica Scandinavica 2000;79:119-22.

[CrossRef] [PubMed]

8. Morcos RN, Gibbons WE, Findley WE. Effect of peritoneal fluid on in vitro cleavage of 2-cell mouse embryos: Possible role in infertility associated with endometriosis. Fertility Sterility 1985;44(5):678-83. [CrossRef] [PubMed]

9. Lessey BA, Castelbaum AJ, Sawin SW, Buck CA, Schinnar $R$, Bilker $W$, et al. Aberrant integrin expression in the endometrium of women with endometriosis. J Clin Endocrinol Metab 1994;79:643-9. [CrossRef] [PubMed]
10. Lessey BA. Medical management of endometriosis and infertility. Fertility Sterility 2000;73:1089-96. [CrossRef] [PubMed]

11. Arici A, Oral E, Bukulmez O, Duleba A, Olive DL, Jones $E E$. The effect of endometriosis on implantation: results from the Yale University in vitro fertilization and embryo transfer program. Fertil Steril 1996;65:603-7. [CrossRef] [PubMed]

12. Azem F, Lessing JB, Geva E, Shahar A, Lerner-Geva L, Yovel I, et al. Patients with stages III and IV endometriosis have a poorer outcome of in vitro fertileization-embryo transfer than patients with tubal infertility. Fertil Steril 1999;72:1107-09. [CrossRef] [PubMed]

13. Huang $H Y$, Lee $C L$, Lai YM, Chang MY, Chang SY, Soong YK. The outcome of in vitro fertilization and embryo transfer therapy in women with endometriosis failing to conceive after laparoscopic conservative surgery. J Am Assoc Gynecol Laparosc 1997;4:299-303. [CrossRef] [PubMed]

14. Kuivasaari $P$, Hippelainen $M$, Antilla $M$, Heinonen S. Effect of endometriosis on IVF/ICSI outcome: stage III/IV endometriosis worsens cumulative pregnancy and live-born rates. Human Reproduction 2005; 20 (11):3130-5. [CrossRef] [PubMed]

15. Coccia ME, Rizello F, Mariani G, Bulletti C.Impact of endometriosis on in vitro fertilization and embryotransfer cycles in young women: a stage-dependent interference. Acta Obstet et Gynecol Scandinavica 2011;90:1232-6. [CrossRef] [PubMed]

16. Vercellini P, Somigliana E, Daguati R, Barbara G, Abbiati $A$, Fedele $L$. The second time around: reproductive performance after repetitive versus primary surgery for endometriosis. Fertil Steril 2009; 92(4): 1253-5. [CrossRef] [PubMed]

17. Berlanda $N$, Vercellini $P$, Fedele $L$. The outcomes of repeat surgery for recurrent symptomatic endometriosis. Curr Opin Obstet Gynecol 2010;22(4):320-5. [CrossRef] [PubMed] 


\title{
SAVETOVANJE BOLESNICA SA PROBLEMOM ENDOMETRIOZE
}

\author{
Sonja Pop Trajković Dinić, ${ }^{1,2}$, Milan Stefanović ${ }^{1,2}$, Radomir Živadinovićc, ${ }^{1,2}$, Vladimir Antić2, \\ Milan Trenkić1,2, Jelena Milošević Stevanović1,2
}

${ }^{1}$ Univerzitet u Nišu, Medicinski fakultet, Niš, Srbija

${ }^{2} U$ niverzitetski klinički centar Niš, Klinika za ginekologiju i akušerstvo, Niš, Srbija

Kontakt: Sonja Pop Trajković Dinić

Oblačića Rada 24/21, 18000 Niš, Srbija

E-mail: sonjapoptrajkovic@gmail.com

\begin{abstract}
Bolesnicama sa problemom endometrioze često je neophodna neka od metoda asistiranih reproduktivnih tehnika, kako bi došle do potomstva. Podaci o ishodu trudnoća kod ovih bolesnica u literaturi su različiti. Cilj ove studije je ispitivanje ishoda vantelesne oplodnje (VTO), kao izbora broj jedan bolesnica sa endometriozom, kako bi se ove bolesnice adekvatno i pravovremeno savetovale. Poredili smo ishod vantelesne oplodnje kod 40 bolesnica sa I i II stadijumom endometrioze, koja je hirurški dijagnostikovana kod 38 bolesnica, koje su imale III i IV stadijum endometrioze. Takođe, poredili smo ishod VTO između 50 bolesnica, koje su jednom operisane od endometrioze bez znakova bolesti u momentu uključivanja u postupak VTO, 29 bolesnica jednom operisanih od endometrioze sa recidivom u momentu uključivanja i 47 bolesnica, koje su 2 i više puta operisane od endometrioze. Ishod vantelesne oplodnje podrazumevao je dobijen broj jajnih ćelija aspiracijom, ukupan broj trudnoća i porođaja. Stopa trudnoća i porođaja bila je niža kod bolesnica sa III i IV stadijumom endometrioze u odnosu na bolesnice sa blagom endometriozom. Stopa implantacije, kliničkih trudnoća i porođaja bila je niža kod bolesnica koje su dva i više puta operisane od endometrioze u odnosu na sve ostale grupe bolesnica. Teži stadijum endometrioze ukazuje na gori ishod u postupku vantelesne oplodnje. Kada govorimo o rekurentnoj endometriozi, ponovna operacija pogoršava ishod vantelesne oplodnje i treba je izbegavati.
\end{abstract}

Acta Medica Medianae 2021;60(3):37-41.

Ključne reči: endometrioza, vantelesna oplodnja, ishod 